https://doi.org/10.15407/ukrbotj76.02.114

\title{
Micromorphological characteristics of the species of Pholiota (Strophariaceae, Basidiomycota) in pure culture
}

\author{
Liubov V. REGEDA, Nina A. BISKO \\ M.G. Kholodny Institute of Botany, National Academy of Sciences of Ukraine \\ 2 Tereschenkivska Str., Kyiv 01004, Ukraine \\ regeda.lyubov@gmail.com
}

Regeda L.V., Bisko N.A. 2019. Micromorphological characteristics of the species of Pholiota (Strophariaceae, Basidiomycota) in pure culture. Ukrainian Botanical Journal, 76(3): 114-120.

Abstract. The article presents results of the research on micromorphology of vegetative mycelia of eight species of the genus Pholiota from the IBK Mushroom Culture Collection of the M.G. Kholodny Institute of Botany, National Academy of Sciences of Ukraine. Using scanning electron microscopy and light microscopy, the micromorphological structures specific to these species were studied in order to enable their identification in pure culture. New data on micromorphology of Pholiota species are given. A set of micromorphological structures was observed for this genus, namely clamp connections, chlamydospores, arthrospores, anastomoses, crystals on hyphae, hyphal rings, rhizomorphs, pellicle spots, hyphae ornamentation, and secretory hyphae. For the first time a detailed study of microstructures of $P$. alnicola, $P$. limonella, $P$. nameko, $P$. populnea, and $P$. subochracea was conducted. Secretory hyphae and vacuolized mycelia in pure culture were noticed only for $P$. populnea. For $P$. subochracea, various hyphae ornamentation on vegetative mycelium was demonstrated. New information about the presence of hyphal rings for three Pholiota species, P. alnicola, P. limonella, and $P$. subochracea, is presented.

Keywords: light microscopy, macrofungi, micromorphological structures, Pholiota, pure culture, scanning electron microscopy, vegetative mycelium

Регеда Л.В., Бісько Н.А. 2019. Мікроморфоогічні характеристики видів роду Pholiota (Strophariaceae, Basidiomycota) у чистій культурі. Український ботанічний журнал, 76(3): 114-120.

Інститут ботаніки ім. М.Г. Холодного НАН України

вул. Терещенківська 2, Київ, 01004, Україна

Резюме. Представлені результати досліджень мікроморфології вегетативного міцелію восьми видів роду Pholiota з Колекції культур шапинкових грибів Інституту ботаніки ім. М.Г. Холодного НАН України (ІВК). За допомогою світлової мікроскопії та сканувальної електронної мікроскопії були вивчені мікроморфологічні структури, специфічні для цих видів та необхідні для їхньої ідентифікації в чистій культурі. Наведено нові дані з мікроморфології видів роду Pholiota. Відмічено сукупність мікроморфологічних структур, а саме: пряжки, хламідоспори, артроспори, анастомози, кристали на гіфах, гіфальні кільця, ризоморфи, міцеліальні плівки, секреторні гіфи на вегетативному міцелії, орнаментація гіф. В нашому дослідженні вперше проведено детальне вивчення мікроструктур P. alnicola, P. limonella, P. nameko, P. populnea та $P$. subochracea для уточнення морфологічних характеристик та надійної ідентифікації цих видів у чистій культурі. Лише для $P$. populnea було відмічено існування секреторних гіф і вакуолізованого міцелію. Для $P$. subochracea отримана інформація щодо орнаментації гіф на вегетативному міцелії. Гіфальні кільця вперше виявлені у трьох видів - P. alnicola, P. limonella і P. subochracea.

Ключові слова: вегетативний міцелій, макроміцети, мікроморфологічні структури, світлова мікроскопія, сканувальна електронна мікроскопія, чиста культура, Pholiota

\section{Introduction}

About 470 species of the genus Pholiota (Fr.) P.Kumm. are known worldwide (http://www.mycobank.org), 25 of them have been reported for Ukraine (Zerova, 1979; Dudka et al., 2009). Mushrooms received attention due to combination of nutritious properties with health-stimulating and medicinal effects (Kim et al., 2006). Anticarcinogenic, antioxidant, antimicrobial and immunomodulating properties of the components isolated from mycelia and fruit bodies of this genus have

(C) 2019 L.V. Regeda, N.A. BIsko been established (Cho et al., 2003; Kim et al., 2006; Zhang et al., 2009). Using mushrooms as a source of preventive and therapeutic agents and their cultivation in the industrial scale have been realized after many years of fundamental research of biology of macrofungi, peculiarities of their growth and development, and nature and mechanisms of metabolic and enzymatic activity (Wasser, 2010). Fruit bodies of $P$. adiposa and $P$. nameko are cultivated in the countries of Southeast Asia in the industrial scale (Pegler, 2003; Gizaw, 2015).

Taxonomic features of macrofungi can be used for their identification in pure culture, therefore research 
Table 1. List of the studied Pholiota species and strains

\begin{tabular}{|l|c|c|}
\hline \multicolumn{1}{|c|}{ Species } & IBK strain & Origin of culture, year \\
\hline Pholiota adiposa (Batsch) P.Kumm. & 2169 & Ukraine, Kyiv, on Populus, 2011 \\
\hline Pholiota alnicola (Fr.) Singer & 2406 & Ukraine, Ivano-Frankivsk Region, Halych, Halych National Nature Park, 2015 \\
\hline Pholiota aurivella (Batsch) P.Kumm. & 2605 & Ukraine, Kyiv Region, Vasylkiv, 2018 \\
\hline Pholiota limonella (Peck) Sacc. & 2335 & Ukraine, Kamianets-Podilskyi, 2013 \\
\hline Pholiota nameko (T.Ito) S.Ito \& S.Imai & 2154 & Obtained from TSAU (AM2), Melitopol, Ukraine, 2011 \\
\hline Pholiota populnea (Pers.) Kuyper \& Tjall.-Beuk. & 2602 & Ukraine, Kyiv, on Populus, 2018 \\
\hline Pholiota squarrosa (Oeder) P.Kumm. & 2010 & Obtained from MSU (3935), Moscow, Russia, 2009 \\
\hline Pholiota subochracea (A.H.Sm.) A.H.Sm. \& Hesler & 2535 & Ukraine, Kyiv Region, Kyyliv, on soil, 2017 \\
\hline
\end{tabular}

MSU - Moscow State University, Moscow, Russia; TSAU - Tauria State Agrotechnological University, Melitopol, Ukraine

on their micromorphological structures is important. Micromorphological characteristics of Basidiomycetes include a set of microscopic features such as presence of clamp connections or pseudo-clamp connections, width and types of hyphae according to the traditional classification by Stalpers (1978), presence of anastomoses and various structures formed during differentiation of the hyphae in culture (hyphal rings, rhizomorphs, inlaid hyphae, crystals on hyphae, etc.), presence of asexual reproduction structures (Mykhaylova, 2014).

This study was focused on micromorphological structures of eight species of the genus Pholiota preserved in the IBK Mushroom Culture Collection.

The study of microstructures of the Pholiota species was traditionally conducted based on fruiting bodies collected in natural habitats (Sawyer, 1917; Hesler, 1968; Farr et al., 1977; Farr, 1985; Smith, Adamcik et al., 2006; Kirk et al., 2008; Chang, Hayes, 2013). In contrast, in pure culture these species were poorly studied. Microstructures only of few species from the genus Pholiota were investigated, P. adiposa, P. aurivella, P. lenta, P. nameko, and P. squarrosa (Yoshinori et al., 1999; Buchalo, Didukh, 2005; Buchalo et al., 2009, 2011; Dyakov et al., 2011). Our research was aimed at studying microstructures of some of these and other species of the genus.

\section{Materials and methods}

Eight strains of Pholiota species from the IBK Mushroom Culture Collection of the M.G. Kholodny Institute of Botany, National Academy of Sciences of the Ukraine were investigated (Bisko et al., 2016). Some of these strains were obtained in 2017-2018 (Table 1).

Mushroom cultures were grown on glucose peptone yeast agar media; g/l: glucose -25 ; peptone -3 ; yeast extract - 3; $\mathrm{MgSO}_{4}-0.25 ; \mathrm{KH}_{2} \mathrm{PO}_{4}-1 ; \mathrm{K}_{2} \mathrm{HPO}_{4}-1$; agar-agar - 22; $\mathrm{pH}-6.0$ ) in Petri dishes at temperature $26 \pm 1{ }^{\circ} \mathrm{C}$. Mycelia were taken from the cultures in the phase of active growth (3-10 days) and from the long-term cultivation of Pholiota species (2 months). Vegetative mycelium microstructures were studied using Zeiss light microscope (LM) and scanning electron microscopy (SEM). Samples were prepared for light microscopy using distilled water, $10 \% \mathrm{KOH}$ or preparative mixture (glycerin: ethanol: water $=1$ : 1: 1) (Bilay, 1982). Samples were prepared for SEM using the modified method of Quattelbaum and Carner (Quattelbaum, Carner, 1980). Four sterilized square $4 \times 4$ $\mathrm{mm}$ pieces of the cover glass were placed $1-3 \mathrm{~cm}$ away from inoculum into Petri dishes. The cover glasses were removed from the agar media, when mycelia overgrew the surface, and then transferred to a microscopic slide. The slide was then placed into a sealed glass vessel fixed with osmium tetroxide vapor ( $1 \%$ solution) for 8 hours. On fixation, the slides were transferred to an empty Petri dish to dry out for 72 hours. After drying out, samples were covered with gold in the vacuum spray gun JII-4X with rotation (Buchalo, Didukh, 2005). The specimens were examined using the Jeon JSM-6060 LA Scanning Electron Microscope (Japan) and studied at a magnification $\times 1000-10000$.

\section{Results and discussion}

An important taxonomic feature for identification of macrofungi in pure culture is the presence of a unique structure that occur on the mycelium of many species of Basidiomycota clamp connections (Stalpers, 1978; Buchalo, Didukh, 2005). Though the clamp connections are exclusive to this phylum, not all species possess these structures. Regular clamp connections were observed for vegetative mycelia in all studied 

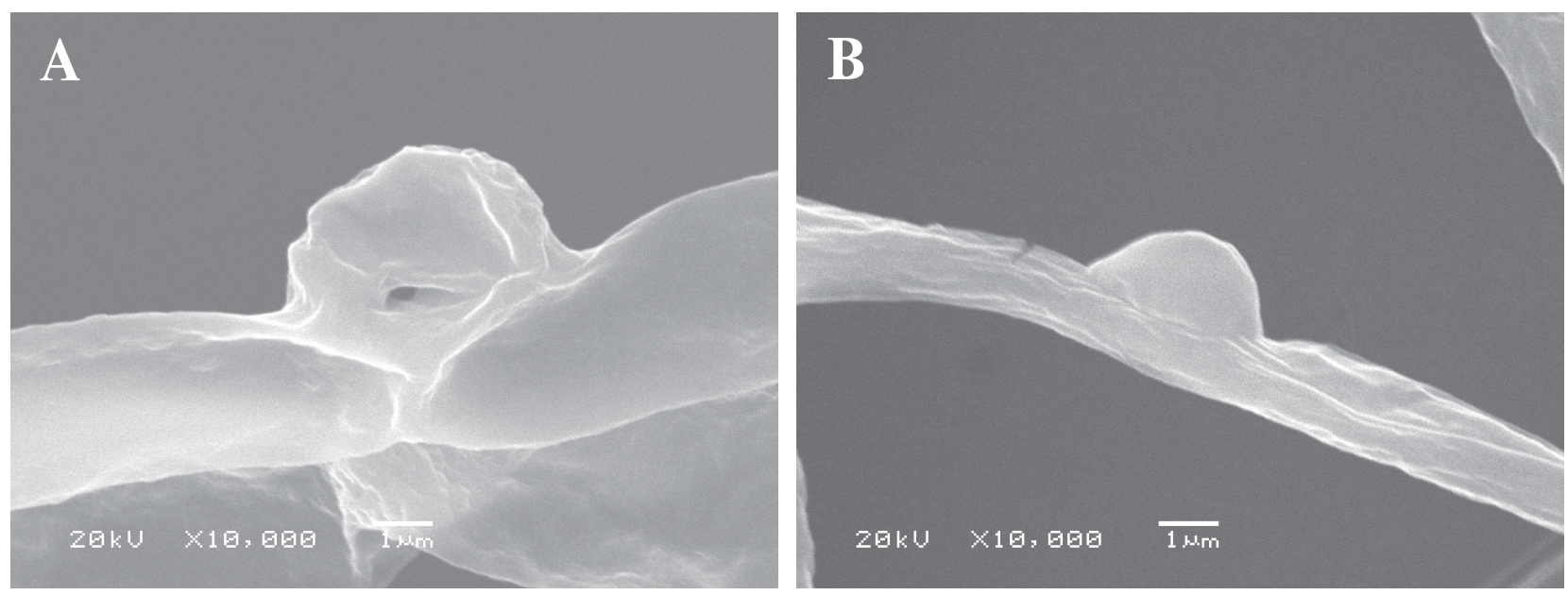

Fig. 1. Clamp connections of Pholiota populnea 2602 (A) and Pholiota adiposa 2169 (B), SEM (×10000)

species (Fig. 1), which agrees with the literature data (Buchalo, Didukh, 2005; Buchalo et al., 2009, 2011; Dyakov et al., 2011).

Vegetative mycelium of Pholiota species in pure culture consist of the thin-walled, moderately branched, regularly septated, uncolored hyphae of $1-3 \mu \mathrm{m}$ in diameter, with anastomoses formed between hyphae (Table 2, Fig. 2, A) and pellicle spots on vegetative mycelium (Table 2, Fig. 2, B). Hyphae fusion is carried out through anastomoses and pellicle spots on vegetative mycelium, which is a well-known phenomenon in the phylum Basidiomycota (Buchalo et al., 2009).
The formation of secretory hyphae and vacuolised mycelium in old cultures were noticed only in P. populnea 2602 (Fig. 3). Similar secretory hyphae were found for Fistulina hepatica (Buchalo et al., 2009), Lepista nuda (Badalyan, Gharibyan, 2017) and vacuolised mycelia for Coprinopsis strossmayeri, Fomitopsis pinicola (Badalyan, Gharibyan, 2017) and Ganoderma adspersum (Badalyan et al., 2019). Hyphae ornamentation that was observed in $P$. subochracea cultures and hyphal rings in old cultures of $P$. alnicola, $P$. limonella and $P$. subochracea can be used as diagnostic taxonomic characters (Fig. 4).
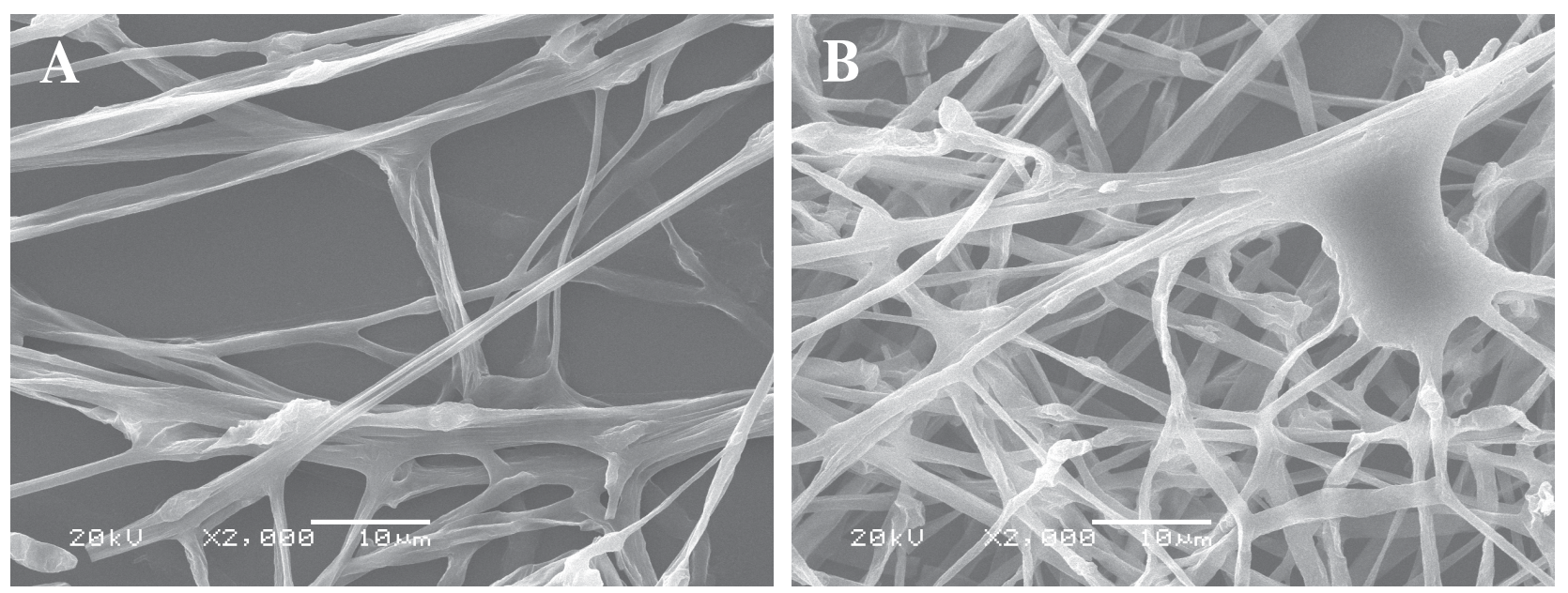

Fig. 2. Anastomoses of Pholiota nameko 2154 (A) and pellicle spot on vegetative mycelia of Pholiota squarrosa 2010 (B), SEM $(\times 2000)$ 

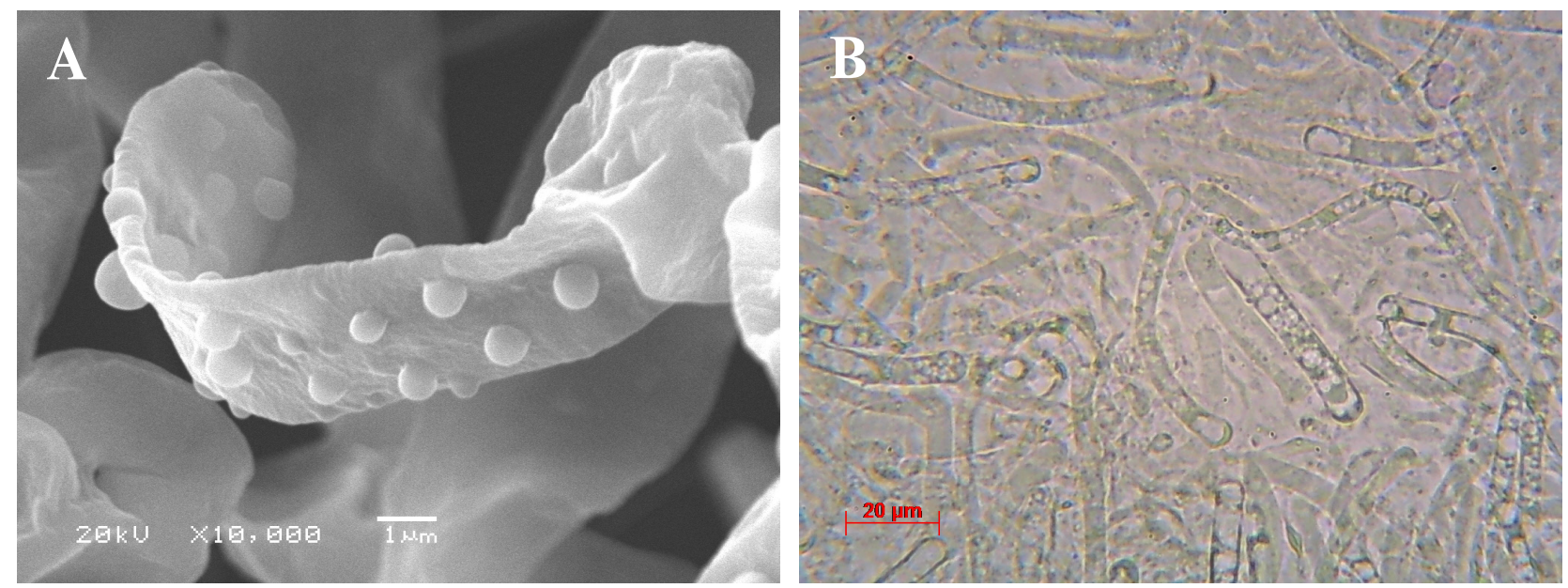

Fig. 3. Exudate on hyphae (A), SEM (×10000) and vacuolised mycelium (B), LM (×40) of Pholiota populnea 2602

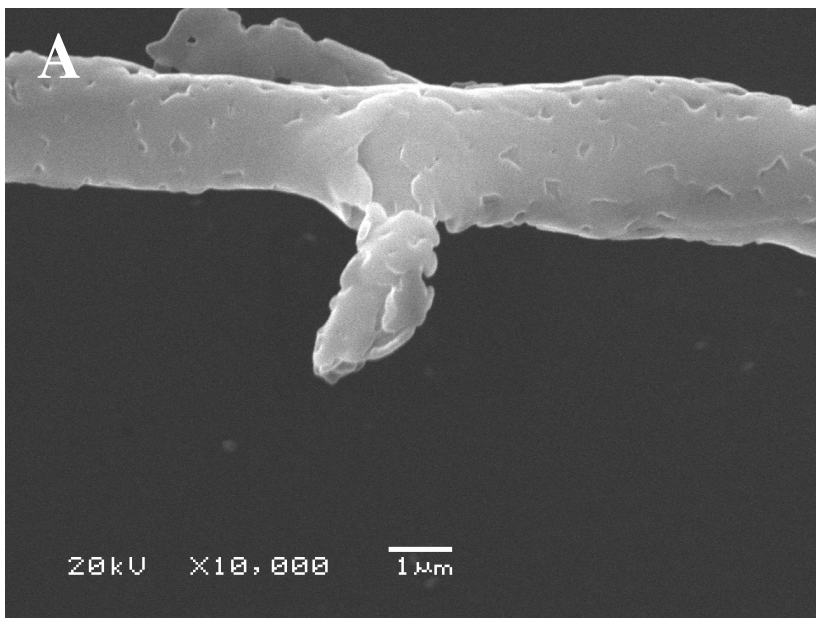

Fig. 4. Hyphae ornamentation (A), SEM $(\times 10000)$ and hyphal rings (B), LM ( $\times 40)$ of Pholiota subochracea
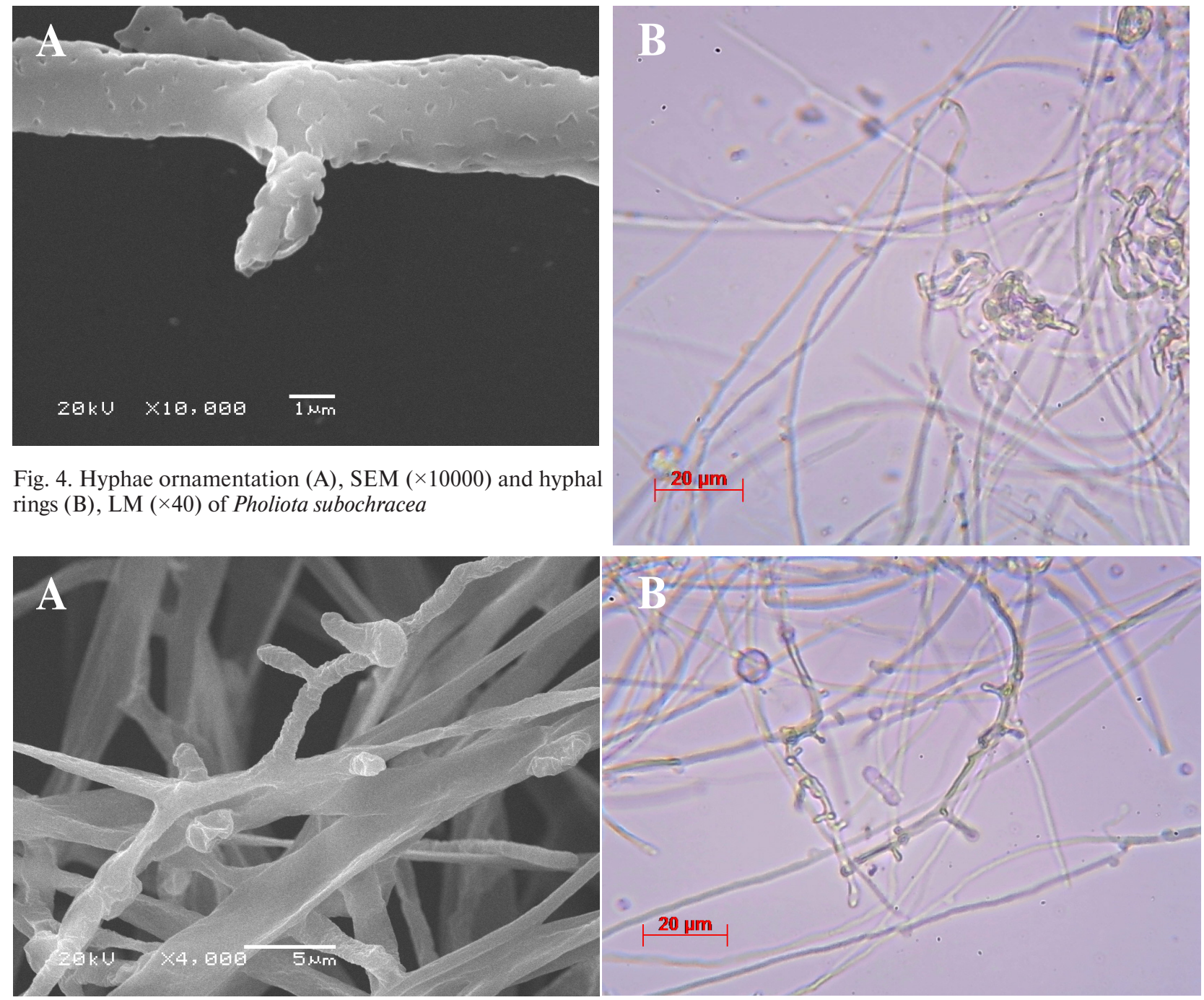

Fig. 5. Conidial sporulation of Pholiota aurivella 2605 (A), SEM $(\times 4000)$, and Pholiota subochracea 2535 (B), LM $(\times 40)$

Український ботанічний журнал, 2019, 76(2) 

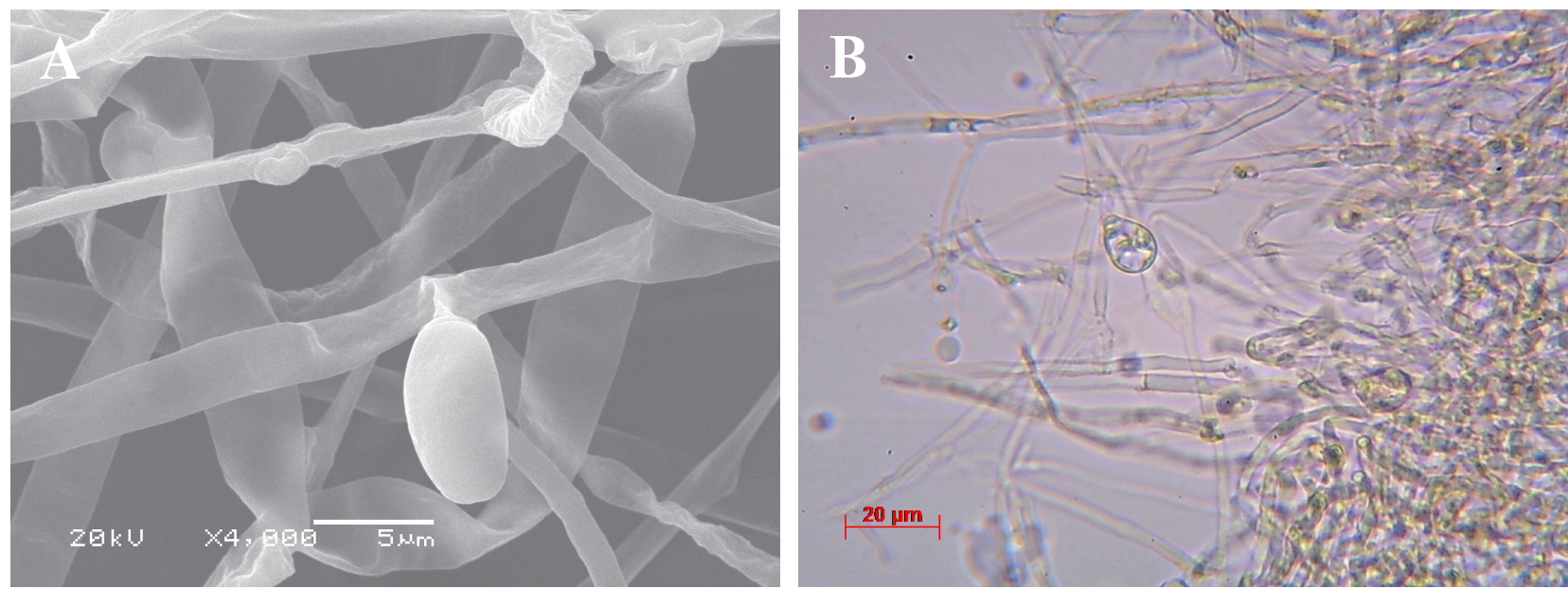

Fig. 6. Chlamydospores of Pholiota limonella 2335 (A), SEM ( $\times 4000)$, and Pholiota alnicola 2406 (B), LM ( $\times 40)$

Species of macrofungi form different structures of asexual reproduction (anamorph structures). Chlamydospores and arthrospores are the most common asexual reproduction structures of Basidiomycota (Buchalo, Diduch, 2005; Buchalo et al., 2011). Anamorphs can be used as a taxonomic criterion at the species level, or sometimes for taxa of higher taxonomic ranks, but most macrofungi do not have these structures. We observed conidial sporulation in all studied cultures (Fig. 5), except $P$. adiposa.

Single intercalary chlamydospores were observed for six cultures $-P$. adiposa, $P$. alnicola, $P$. aurivella, P. limonella, P. nameko, and P. subochracea (Table 2, Fig. 6).

According to literature data (Buchalo, Didukh, 2005; Buchalo et al., 2009; Dyakov et al., 2011), vegetative mycelia of the strains of $P$. adiposa, $P$. aurivella, and $P$. squarrosa are able to form a structure of asexual reproduction, mitotic spores (arthrospores). We observed arthrospores in our experiment only for P. aurivella, P. adiposa, and P. limonella (Fig. 7).

The ability to form crystals is widely known for many species of Basidiomycota which sometimes also depends on the nutrient media and age of the mushroom cultures (Buchalo et al., 2009; Dyakov et al., 2011). Crystal formation was observed in almost all investigated species of Pholiota (Table 2, Fig. 8). The morphology of the crystals is very different. We observed prismatic, cubic, hexahedral, sometimes of the undefined shape crystals. Maximum length of the crystals was $12.2 \mu \mathrm{m}$, minimum $-0.5 \mu \mathrm{m}$, width $-0.3-6.1 \mu \mathrm{m}$.

Thus, presence of clamp connections, ability to form anastomoses and pellicle spots on vegetative mycelia,

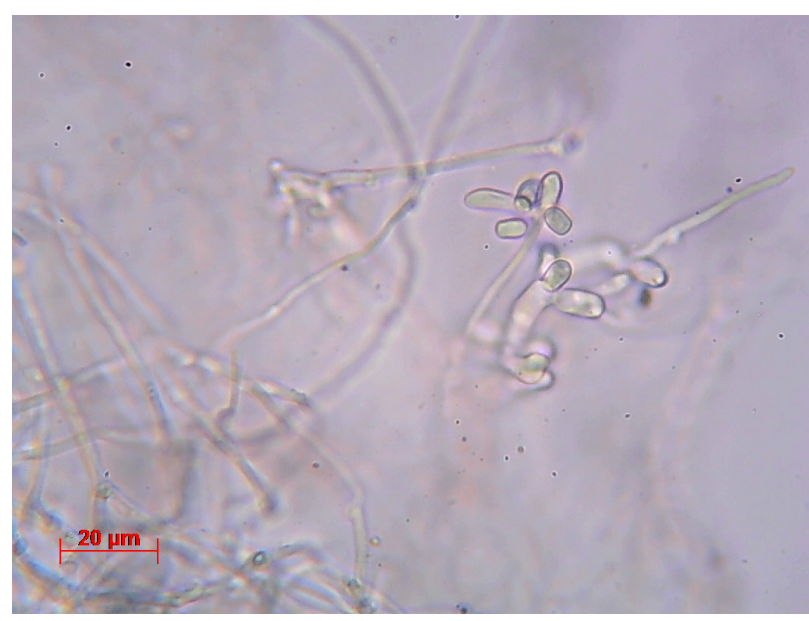

Fig. 7. Arthrospores of Pholiota limonella 2335, LM $(\times 40)$

formation of conidial sporulation, arthrospores and chlamydospores, ability to secrete crystals different in shape and size were observed for various investigated species. Our results confirm some earlier literature data (Buchalo, Didukh, 2005; Buchalo et al., 2009, 2011; Dyakov et al., 2011). Micromorphological characteristics of the studied Pholiota species are shown in Table 2.

\section{Conclusions}

The micromorphological features of eight species of Pholiota from the IBK Mushroom Culture Collection of the M.G. Kholodny Institute of Botany, National Academy of Sciences of Ukraine were established.

For the first time we conducted a detailed study of microstructures of vegetative mycelia of such species 

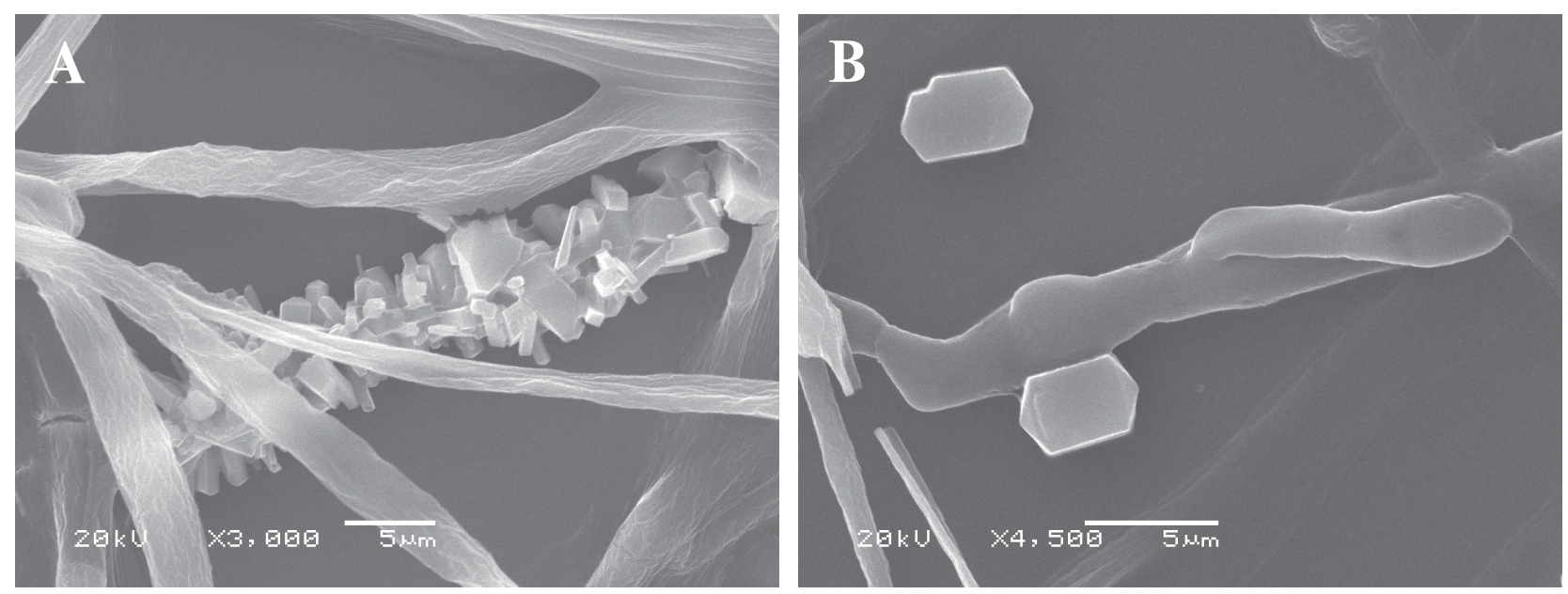

Fig. 8. Crystals of Pholiota adiposa 2169 (A), SEM $(\times 3000)$ and Pholiota alnicola 2406 (B), SEM $(\times 4500)$

as $P$. alnicola, P. limonella, $P$. nameko, P. populnea, and $P$. subochracea for morphological characteristics and identification of these taxa in pure culture. The presence of all typical for the genus features has been noted in various studied species.

New data about micromorphological features of Pholiota species in pure culture were obtained. Only for $P$. populnea the existence of secretory hyphae and vacuolized mycelium and for $P$. subochracea - the hyphae ornamentation on vegetative mycelium were noticed. New information about the presence of hyphal rings for three Pholiota species, P. alnicola, P limonella and $P$. subochracea, is provided.

\section{REFERENCES}

Adamcik S., Holec S.J., Lizon P., Ripkova S., Kučera V. 2006. Notes on taxa of the genus Pholiota described by C. Kalchbrenner. Mycotaxon, 97: 5-12.

Badalyan S.M., Gharibyan N.G. 2017. Characteristics of mycelial structures of different fungal collections. Yerevan: YSU Press, $176 \mathrm{pp}$.

Badalyan S.M., Gharibyan N.G., Iotti M., Zambonelli A. 2019. Morphological and ecological screening of different collections of medicinal white-rot bracket fungus Ganoderma adspersum (Schulzer) Donk (Agaricomycetes, Polyporales). Italian Journal of Mycology, 48: 1-15.

Bilay V.I. 1982. Methods of Experimental Mycology. Kiev: Naukova Dumka, 550 рр. [Билай В.И. 1982. Методы

Table 2. Micromorphological features of vegetative mycelium of Pholiota species

\begin{tabular}{|c|c|c|c|c|c|c|c|c|c|}
\hline Species, strain & 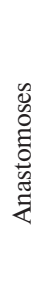 & 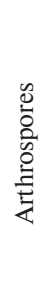 & 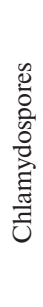 & 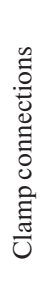 & 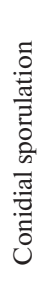 & 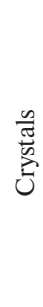 & 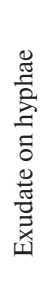 & 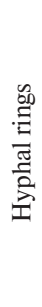 & 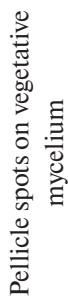 \\
\hline Pholiota adiposa 2169 & + & + & + & + & - & + & - & - & - \\
\hline Pholiota alnicola 2406 & - & - & $+^{*}$ & $+^{*}$ & $+^{*}$ & $+^{*}$ & - & $+^{*}$ & - \\
\hline Pholiota aurivella 2605 & + & + & + & + & + & - & - & - & + \\
\hline Pholiota limonella 2335 & $+^{*}$ & - & $+^{*}$ & $+^{*}$ & $+^{*}$ & $+^{*}$ & - & $+^{*}$ & - \\
\hline Pholiota nameko 2154 & $+^{*}$ & - & $+^{*}$ & $+^{*}$ & $+^{*}$ & $+^{*}$ & - & - & $+^{*}$ \\
\hline Pholiota populnea 2602 & $+^{*}$ & - & - & $+^{*}$ & $+^{*}$ & $+^{*}$ & $++^{*}$ & - & - \\
\hline Pholiota squarrosa 2010 & $+^{*}$ & - & - & + & + & - & - & - & + \\
\hline Pholiota subochracea 2535 & $+^{*}$ & - & $+^{*}$ & $+^{*}$ & $+^{*}$ & $+^{*}$ & - & $+^{*}$ & $+^{*}$ \\
\hline
\end{tabular}

"+" structures found; "-" structures not found; " new data for this species 
экспериментальной микологии. Киев: Наукова думка, 550 c.].

Bisko N.A., Lomberg M.L., Mytropolska N.Yu., Mykchaylova O.B. 2016. The IBK Mushroom Culture Collection. Kyiv: Alterpress, 120 pp. [Бісько Н.А., Ломберг М.Л., Митропольська Н.Ю., Михайлова О.Б. 2016. Колекція культур шапинкових грибів (IBК). Київ: Альтерпрес, 120 с.].

Buchalo A.S., Didukh M.Ya. 2005. Microbiological characteristics of culinary-medicinal mushroom and fungi cultures. International Journal of Medicinal Mushroom, 7: 249-261.

Buchalo A.S., Mykchaylova O.B., Lomberg M.L., Wasser S.P. 2009. Microstructures of vegetative mycelia of macromycetes in pure cultures. Eds P.A. Volz, E. Nevo. Kyiv: Alterpress, 224 pp.

Buchalo A.S., Wasser S.P., Mykchaylova O.B., Bilay V.T., Lomberg M.L. 2011. Taxonomical significance of microstructures in pure cultures of macromycetes. In: Proceedings of the $7^{\text {th }}$ International Conference on Mushroom Biology and Mushroom Products (ICMBMP7, 4-7October 2011, Arcachon, France). Arcachon, pp. 50-57.

Chang S.T., Hayes W.A. 2013. The biology and cultivation of edible mushrooms. New York: Academic Press, 842 pp.

Cho Y.-H., Kong W.-S., Kim G.-H., Jhune C.-S., You C.-H., Yoo Y.-B., Kim K.-H. 2003. Analysis of cultural characteristics and phylogenic relationship of collected strains of Pholiota species. Mycrobiology, 31(4): 200-204.

Dudka I.O., Heluta V.P., Andrianova T.V., Hayova V.P., Tykhonenko Yu.Ya., Prydiuk M.P., Holubtsova Yu.I., Krivomaz T.I., Dzhagan V.V., Leontyev D.V., Akulov O.Yu., Sivokon O.V. 2009. Fungi of Nature Reserves and National Parks of Eastern Ukraine, vol. 2. Kyiv: Aristey, 428 pp. [Дудка I.О., Гелюта В.П., Андріанова Т.В., Гайова В.П., Тихоненко Ю.Я., Придюк М.П., Голубцова Ю.І., Кривомаз Т.І., Джаган В.В., Леонтьєв Д.В., Акулов О.Ю., Сивоконь О.В. 2009. Гриби заповідників та національних парків Лівобережної України. Київ: Арістей, 428 с.].

Dyakov M.Yu., Kamzolkina O.V., Shtaer O.V., Bisko N.A., Poedinok N.L., Michailova O.B., Tikhonova O.V., Tolstikhina T.E., Vasil'eva B.F., Efremenkova O.V. 2011. Morphological characteristics of natural strains of certain species of Basidiomycetes and biological analysis of antimicrobial activity under submerged cultural conditions. Microbiology, 80(2): 274-285.

Farr D. 1985. Scanning electron microscopic observations of basidiospores in Pholiota and related genera. Canadian Journal of Botany, 63(3): 603-610.

Farr E.R., Miller O.K, Farr D.F. 1977. Biosystematic studies in the genus Pholiota, stirps Adiposa. Canadian Journal of Botany, 55: 1167-1180.
Gizaw B. 2015. Cultivation and yield performance of Pholiota nameko on different agro industrial wastes. Academia Journal of Food Research, 3(3): 32-42.

Kim J.-H., Lee D.-H., Choi S.-Y., Park J.S., Lee J.-S. 2006. Effects of Lycii fructus and Edible Mushroom, Pholiota adiposa, on the Quality and Angiotensin I-Converting Enzyme Inhibitory Activity of Korean Traditional Rice Wine. Food Biotechnology, 20: 183-191.

Kirk P.M., Cannon P.F., Minter D.W., Stalpers J.A. 2008. Dictionary of the Fungi. $10^{\text {th }}$ ed. Wallingford, UK: CAB International, $524 \mathrm{pp}$.

Mykchaylova O.B. 2014. Morphological and cultural properties of a medicinal mushroom, Piptoporus betulinus (Basidiomycetes), on nutrient media. Ukrainian Botanical Journal, 71(5): 603-609. [Михайлова О.Б. 2014. Морфолого-культуральні властивості лікарського гриба Piptoporus betulinus (Basidiomycetes) на агаризованих живильних середовищах. Український ботанічний жсурнал, 71(5): 603-609]. https://doi.org/10.15407/ ukrbotj71.05.603

Pegler D.N. 2003. Useful fungi of the world: the Shii-take, Shimeji, Enoki-take, and Nameko mushrooms. Journal of Mycology, 17: 3-5.

Quattelbaum D., Carner G.R. 1980. A technique for preparing Beauveria spp. for scanning electron microscopy. Canadian Journal of Botany, 58: 1700-1703.

Sawyer W.H. 1917. Development of some species of Pholiota. Botanical Gazette, 64(3): 206-229.

Smith A.H., Hesler L.R. 1968. The North American Species of Pholiota. New York: Hafner Publishing Company, 349 pp.

Stalpers J.A. 1978. Identification of wood-inhabiting Aphyllophorales in pure culture. Studies in Mycology, 16, 248 pp.

Wasser S.P. 2010. Medicinal mushrooms science: history, current status, future trends and unsolved problems. International Journal of Medicinal Mushroom, 12(1): 1-16.

Yoshinori C.H., Takeo T.K., Kitamoto Y. 1999. Morphological and cytological aspects of oidium formation in a basidiomycete, Pholiota nameko. Mycoscience, 40(2): 95-101.

Zerova M.Ya. 1979. Basidiomycetes. In: Handbook of Fungi of Ukraine, vol. 5, issue 2. Eds M.Ya. Zerova, P.E. Sosin, G.L. Rozhenko. Kyiv: Naukova Dumka, 323 pp. [3epoва М.Я. 1979. Базидіоміцети. В кн.: Визначник грибів України, т. 5, ч. 2. Ред. М.Я. Зерова, П.Є. Сосін, Г.Л. Роженко. Київ: Наукова думка, 323 с.].

Zhang G.Q., Sun J, Wang H.X., Ng T.B. 2009. A novel lectin with antiproliferative activity from the medicinal mushroom Pholiota adiposa. Acta Biochimica Polonica, 56(3): 415-421.

Рекомендує до друку

Надійшла 19.02.2019

М.М. Сухомлин 